\title{
DIFFERENCES BETWEEN FACULTY AND STUDENTS' PERCEPTION OF RECRUITMENT TECH NIQUESTHAT INFLUENCE STUDENTS TO ATTEND FOUR-YEAR AUTOMOTIVE PROGRAMS
}

\author{
G regory Belcher \\ Robert Frisbee
}

Pittsburg State University

Brian Sandford

The Ohio State University

\begin{abstract}
The purpose of this study was to identify if differences existed between the perceptions of importance of recruitment techniques as reported by students within baccalaureate automotive technology programs and the faculty members who teach in these programs. Participants in the study were 382 students (Freshmen through Seniors) and 27 faculty members of the eight universities in the United States that offer automotive technology baccalaureate degrees. The survey instrument used in this study employed a scale to measure the perceptions of the students and faculty members concerning the importance of selected recruitment items. Overall, the responses between the faculty and the students were similar. Reputation of the automotive program, reputation of the university, campus visits and high school/community college teacher/counselor were four of the top five most effective recruitment items reported by both groups. Students and faculty differed in that students indicated parent/relatives were more important to them in the recruitment process than what the faculty perceived them to be, and the faculty revealed that friends at the university/community college/ high school, alumni of the university, and articulation or direct transfer from a community college were more important recruitment items than did the students.
\end{abstract}

\section{INTRODUCTION}

There are few occupations that the growth of technology has not affected or influenced in some way. Automotive technology is an occupation that has been, and will continue to be, affected by changing technology and industry standards. Current automobiles are a challenge to repair because of this advanced technology, but the future automobile will be even more complicated (Riley, 1995). This advanced and continuously evolving technology will require automotive technicians to have greater skills and knowledge in the areas of both repair and maintenance. Individuals working in the area of service management also need advanced knowledge and skills to deal with the changes brought about by technology. Service managers 
and technicians with advanced automotive technical skills are in demand, and it is anticipated that the need will even be greater in the future (Cornish, 1996; Frisbee, 1997). A tremendous growth within the automotive industry is expected during the next 10-25 years. Findings by Cornish and Riley indicate that change in this industry will be unprecedented and the rate of global change will continue to accelerate. Frisbee stated that universities currently need increased enrollment within four-year automotive programs to prepare enough individuals to meet the future needs. Effective recruitment of students is one method to increase enrollment within these programs. Baldridge, Kemerer, and Green (1982) found that university faculty are a key component in the enrollment process of which recruitment is a valuable and necessary part. Astone and Nunez-Wormack (1991) concurred with Baldridge et. al and stated recruitment of students should engage all constituencies of the college including the faculty.

\section{Conceptual Framework}

To effectively recruit students, knowing the factors and degrees of influence which lead them to select and enroll in a school is important. In addition, if instructors within these four-year programs are considered an important component in the recruitment process (Baldridge, Kemerer \& Green, 1982; Astone \& Nunez-Wormack, 1991), then knowing if instructors have similar perceptions to students concerning what influenced them to attend these schools will help ensure that the energies and finances spent on recruitment activities are legitimate and effective.

\section{Problem Statement}

Recruitment efforts are a major component for enhancing enrollment and it has been indicated that faculty play an integral role in the recruitment process for universities. Are the recruitment techniques that students perceive as important similar to those for which faculty discern as important?

\section{Purpose of Study}

The purpose of this study was to identify whether there was a match between what students and faculty members perceive as important recruitment techniques for baccalaureate automotive technology programs.

\section{Identified Factors That Influence Student Enrollment Behavior}

Frisbee (1997) identified seventeen factors that influenced student enrollment in four year automotive technology programs. The instrument and data previously collected from students by Frisbee (1997) was used to compare to additional data collected from four year automotive instructors. Frisbee originally found sixteen items from the review of literature when developing the survey instrument, and an additional item (reputation of the automotive program) was added as a result of establishing the instrument's content validity. The seventeen items found to influence student decisions to attend four year automotive programs were: (a) friend(s) at university/ community college or high school (Hossler, Bean \& Associates, 1990; Edmunds, 1980) (b) reading 
the university's catalog (Hossler et al., 1990; Paulsen, 1990), (c) high school/community college counselor/teacher (Devier, 1982; Edmunds, 1980; Isbell \& Lovedahl, 1989; Izadi \& Toosi, 1995), (d) parent(s)/relatives (Hossler et al., 1990; Major, 1991; Mitchell, 1994; Speelman \& Stein, 1993), (e) alumni of the university (Devier, 1982; Edmunds, 1980; Hossler et al., 1990; Isbell \& Lovedahl, 1989), (f) reputation of automotive program (Frisbee, 1997), (g) technology recruitment activities (Izadi \& Toosi, 1995), (h) university recruiters visiting my high school (Hossler et al., 1990), (i) athletic advisor/coach (Izadi \& Toosi, 1995), (j) admission office at the university (Paulsen, 1990; Hossler et al., 1990), (k) campus visit ( Hossler et al., 1990; Isbell \& Lovedahl, 1989; Litten, 1989; Wanat \& Bowles, 1992), (l) reputation of the university (Paulsen, 1990), (m) university recruiters visiting my community college ( Hossler et al., 1990; Williams, 1993), (n) community in which university is located (Paulsen, 1990; Ihlanfeldt, 1980), (o) bulletin board advertising at my previous school (Izadi \& Toosi, 1995), (p) promotional materials (Hossler et al., 1990; Owens, 1989; Mobley, 1988), and (q) articulation or direct transfer from community college (Bickart, 1991; Isbell \& Lovedahl, 1989; Shaw, 1994).

The literature indicates that instructors also play an important role in the recruitment process. In previous studies (Craft, 1980; Edmunds, 1980; Hossler et al., 1990; Isbell \& Lovedahl, 1989; Litten, 1989; Mobley, 1988; Wanat \& Bowles, 1992; Williams, 1993) it was found that campus visits played an important role in influencing a student decision to enroll in the school. Faculty, of course are an integral part of these campus visits and often provide both the primary contact and any lasting impressions for prospective students. Research by Wanat and Bowles (1992) specifically showed the importance of personalized tours of laboratory and program areas conducted by faculty concerning their effect on student recruitment. Williams (1993) found that the number one ranked recruitment strategy by student responses was high school visits by faculty members of the four year institution. Mobley (1988) determined that college faculty also play an important role in communicating with prospective students either by telephone or written communications. Additionally, four-year faculty members tend to maintain contact with high school teachers who provide them information about perspective students (Devier, 1982). Lastly, reputation of the automotive program was found by Frisbee (1997) to be the number one influence of students to attend a four year automotive program, and the faculty of these programs have a vested interest in developing and maintaining the reputation of these programs.

\section{METHOD}

\section{Population}

The overall population for this study were students and faculty of the automotive technology programs in the eight universities in the United States that offer automotive technology baccalaureate degrees (Ferris State University, Pittsburg State University, Southern Illinois University at Carbondale, University of Southern Colorado, Central Missouri State University, Weber State University, Montana State University - Northern, and Indiana State University). The population consisted of all faculty members, Freshmen, Sophomores, Juniors and Seniors from each of the eight universities. The accessible population was comprised of 607 students and 36 faculty members. 


\section{InSTRUMENTATION}

A survey instrument developed by Frisbee (1997) based upon the review of literature and published instruments (Bickart, 1991; Devier, 1982; Isbell and Lovedahl, 1989; Izadi and Toosi, 1995; Sanders, 1986; Speelman and Stein, 1993; Williams, 1980) was the platform used to develop the survey instrument for this study. The questionnaire consisted of seventeen items utilizing a fivepart Likert-type scale with the following descriptors: $1=$ not important, $2=$ slightly important, 3 =important, $4=$ quite important, and $5=$ very important.

A panel of experts was used to establish content and face validity for the instrument. The panel consisted of three four-year automotive faculty, twenty four-year automotive students, one admission/recruitment specialist, one technical education faculty member, and four occupational and adult education faculty members. The panel of experts was asked to confirm that the instrument had clearly defined items which represented the domain of interest in this study, make changes or offer suggestions for the addition or deletion of items, and evaluate the overall format and appearance of the instrument. The additional item of "Reputation of Automotive Program" was added to the instrument, based on panel member input.

After revisions were made to the instrument reflecting panel member recommendations, a pilot test was conducted using a group of twenty students in a four-year automotive technology course at Pittsburg State University (these students were not the same students who served on the panel of experts). To measure internal consistency a Cronbach= $\partial s$ alpha was calculated resulting in a $\mathrm{r}=.84$. The twenty students who participated in the pilot study were included in the final population of this study.

\section{Procedure}

The automotive technology department chairpersons for each of the eight universities were contacted by telephone by the researchers to request their participation in this study. A packet of instruments were then sent to each chairperson with instructions on how to administer the surveys. Of the 607 student surveys sent, 383 (63.09\%) were returned. Of the 383 student surveys returned, $382(99.74 \%)$ were usable. Of the 36 faculty that were surveyed, 27 were returned and usable (75\% response rate).

\section{RESULTS}

Overall means for the faculty responses show that all but one of the items on the survey were more important to them when compared to the student means (Table 1). In other words, the findings indicate that faculty believe that most of the recruitment techniques are important to influencing students decisions to attend a four-year automotive program. Student's perceptions toward the importance of items, however, were in general lower and fewer items achieved the same degree of importance as those of the faculty.

Several items were similar in ranking of importance between students and faculty. These included: (a) reputation of the automotive program; (b) reputation of the university; (c) campus visits; and (d) high school/community college teacher/counselor. These four recruitment techniques were within the top five ratings of each group, and the recruitment item of reputation of automotive program was rated as most important by both groups. Student respondents indicated that parent/relatives were more important to them in the recruitment process than what faculty indicated. Faculty perceived that alumni of the university were quite important, 
whereas the students rated this item as only slightly important. Friends at the university/community college/high school, and articulation or direct transfer from a community college were perceived by faculty to be more important in contrast to what students felt were important to them.

Table 1

Student and Faculty Responses to the Seventeen Recruitment Techniques

\begin{tabular}{|c|c|c|c|c|c|c|}
\hline \multirow[t]{2}{*}{ Recruitment Technique } & \multirow[t]{2}{*}{$\begin{array}{l}\text { Student } \\
\text { Ranking }\end{array}$} & \multicolumn{2}{|c|}{$\begin{array}{l}\text { Student } \\
\text { Response }\end{array}$} & $\begin{array}{c}\text { Faculty } \\
\text { Ranking }\end{array}$ & \multicolumn{2}{|c|}{$\begin{array}{l}\text { Faculty } \\
\text { Response }\end{array}$} \\
\hline & & $M$ & $S D$ & & $M$ & $S D$ \\
\hline $\begin{array}{l}\text { Reputation of Automotive } \\
\text { Program }\end{array}$ & 1 & 4.39 & 98 & 1 & 4.78 & .42 \\
\hline Reputation of the University & 2 & 3.86 & 1.25 & 5 & 4.11 & .89 \\
\hline Campus Visit & 3 & 3.37 & 1.34 & 2 & 4.30 & .67 \\
\hline Parent(s)/Relatives & 4 & 3.26 & 1.41 & 7 & 3.85 & .92 \\
\hline $\begin{array}{l}\text { High School/Comm. College } \\
\text { Counselor/Teacher }\end{array}$ & 5 & 2.95 & 1.47 & 4 & 4.22 & .85 \\
\hline Technology Recruitment Activities & 6 & 2.90 & 1.43 & 9 & 3.78 & .89 \\
\hline $\begin{array}{l}\text { Friends at University/ } \\
\text { Community College/High School }\end{array}$ & 7 & 2.83 & 1.51 & 3 & 4.26 & .81 \\
\hline Reading University Catalog & 8 & 2.74 & 1.21 & 16 & 2.73 & .87 \\
\hline $\begin{array}{l}\text { Community in which University } \\
\text { is Located }\end{array}$ & 9 & 2.74 & 1.46 & 12 & 3.30 & .78 \\
\hline $\begin{array}{l}\text { Promotional Material } \\
\text { (Brochures, Letters, Video) }\end{array}$ & 10 & 2.60 & 1.40 & 10 & 3.67 & .73 \\
\hline Alumni of this University & 11 & 2.51 & 1.44 & 6 & 4.04 & .90 \\
\hline $\begin{array}{l}\text { Articulation or Direct Transfer } \\
\text { from Community College }\end{array}$ & 12 & 2.29 & 1.48 & 8 & 3.85 & .82 \\
\hline $\begin{array}{l}\text { Admission Office at This } \\
\text { University }\end{array}$ & 13 & 2.25 & 1.32 & 14 & 2.85 & .99 \\
\hline $\begin{array}{l}\text { University Recruiters Visiting } \\
\text { High School }\end{array}$ & 14 & 2.29 & 1.43 & 13 & 3.15 & .99 \\
\hline $\begin{array}{l}\text { University Recruiters Visiting } \\
\text { my Community College }\end{array}$ & 15 & 2.04 & 1.40 & 11 & 3.52 & 1.12 \\
\hline $\begin{array}{l}\text { Bulletin Board Advertising at } \\
\text { my Previous School }\end{array}$ & 16 & 1.90 & 1.26 & 14 & 2.85 & .82 \\
\hline Athletic Advisor/Coach & 17 & 1.78 & 1.14 & 17 & 2.15 & .99 \\
\hline
\end{tabular}




\section{ConCLUSIONS}

A rank order of the means shows that four out of the top five recruitment items were similar in degree of importance between the student and faculty groups. These four items were: (a) reputation of the automotive program, (b) reputation of the university; (c) campus visit, and (d) high school/ community college teacher/counselor. This indicates that faculty tend to agree about what they perceive are the main techniques which positively influence a student's decision to attend a fouryear automotive program.

Although the results are similar for both groups in some respects, it should be noted that there are differences as well. Based upon the higher item means by faculty, it was concluded that faculty deemed most all of the recruitment techniques as important to very important, whereas students had only a few items rated this high. This may indicate that faculty value the importance of some recruitment items that students do not necessarily see as important or influential to them.

Faculty perceived several recruitment techniques as quite important ( $\underline{M}$ greater than 3.5$)$, whereas students indicated these items to be of lesser importance ( $\mathrm{M}$ of 3.37 and less). These items include: campus visits, parent/relatives, high school/community college counselor/teacher, technology recruitment activities, friends at the university/community college/high school, promotional materials, alumni of the university, articulation or direct transfer from community college, and university recruiters visiting my community college. The disparity in responses may indicate that faculty who utilize these different recruitment efforts may be better off devoting their resources in other recruitment areas which students indicated were more important or influential to their decision to attend a four-year automotive technology program.

\section{Recommendations and Implications}

Persons who are involved in automotive technology recruitment should become familiar with the findings of this study. In order to enhance student recruitment, specifically for four-year automotive technology programs, there are certain areas in which recruiters should focus their time and efforts. Each of these areas will be discussed individually.

The reputation of the automotive programs can be communicated to prospective students in several ways. Examples may include: (a) job placement statistics showing successful employment after program completion and comparisons to similar types of programs can be made available to students; and (b) reputation of the program and career opportunities should be emphasized when faculty visit high schools and community colleges.

Recruiters need to remain aware of the influence that parents and relatives have over prospective students. As much as possible, while visiting with prospective students, faculty should also strive to make contact and open lines of communication with the students' parents and relatives.

Campus visits should remain as a part of the recruitment process to enhance the enrollment of students in four-year automotive programs. If program recruiters are not currently using this method for recruitment, it is recommended that they begin doing so. Conversely, if this process is already in use by recruiters, it is recommended that they maintain such practices. 
Faculty that recruit students for four-year automotive programs may need to place less emphasis on the alumni of the program, articulation or direct transfer from the community college, and friends at the university/community college/high school. Rather, faculty may want to place more emphasis on the reputation of the university and parent(s)/relatives, when recruiting students.

Vocational/technical programs (other than four year automotive programs) could benefit from this information as well. Much of the recruitment literature comes from the university level and only focuses on academic programs. Vocational and technical program recruiters may need to identify and utilize different approaches to the recruitment process than what is currently being used by academic program areas. Other vocational and technical education teachers should pay particular attention to factors that students deem important to them in the recruitment process.

Little is known about faculty and students perceptions of the effectiveness of different recruitment strategies in career and technical education. It is recommended that more in-depth research using qualitative methods be used to provide more insightful data in this area, by interviewing students and faculty members.

\section{References}

Astone, B. \& Nunez-Wormack, E. (1991). Pursuing diversity: Recruiting college minority students. Association for the Study of Higher Education. (ERIC Document Reproduction Service No. 333856).

Baldridge, J. V., Kemerer, F. R. \& Green, K. C. (1982). The Enrollment Crisis: Factors, Actors, and Impacts. AAHE-ERIC Higher Education Research Report No. 3, 1982. Washington, D.C.:The George Washington University, School of Education and Human Development.

Bickart, T.A. (1991, May/June). Gateway to pluralism: Recruitment and retention. Engineering Education, 419-424.

Craft, C.O. (1980, February), Recruitment of industrial arts education majors: A professional obligation of all industrial arts educators. Man /Society/Technology, 21-22.

Cornish, E. (1996). The cyber future: 92 ways our lives will be changed by the year 2025. The Futurist, 30(1), 27-67.

Devier, D.H. (1982). The recruitment of industrial arts teacher education students in Ohio with possible implications for the total profession. Journal of Industrial Teacher Education, 19(3), 27-38.

Edmunds, N.A. (1980). Effective recruiting: A pool to replenish, sustain, and improve the profession. The Journal of Epsilon Pi Tau, 6(1), 17-22.

Frisbee, R. L. (1997). A study of student recruitment in automotive technology baccalaureate degree programs. Unpublished doctoral dissertation, Oklahoma State University.

Hossler, D., Bean, J.P., \& Associates. (1990). The Strategic Management of College Enrollments. San Francisco: Jossey-Bass, Inc.

Ihlanfeldt, W. (1980). Achieving optimal enrollments and tuition revenues: A guide to modern methods of market research, student recruitment, and institutional pricing. San Francisco: JosseyBass.

Isbell, C.H. \& Lovedahl, G. G. (1989). A survey of recruitment techniques used in industrial arts/technology education programs. The Journal of Epsilon Pi Tau, 15(1), 37-41. 
Izadi, M., \& Toosi, M. (1995). Effective recruitment techniques as identified by students majoring in industrial technology. Journal of Industrial Technology, 11(3), 13-16.

Litten, L.H. (1989). You can't get much from watching the radio. Journal of College Admissions, 119, 7-17.

Major, D. R. (1991). An assessment of the importance of selected factors influencing day-time adults to attend Indian Meridian Area Vocational-Technical School. Unpublished masters thesis, Oklahoma State University.

Mitchell, G. L. (1994). Selected factors and perceptions influencing high school students not to attend Meridian Technology Center. Unpublished masters thesis, Oklahoma State University.

Mobley, J. (1988). Selling students the three T's: Tools, technology and thinking. School Shop, 48(5), 9-11.

Owens, J. R. (1988/89). Recruiting females into industrial technology in Louisiana. Journal of Industrial Technology, 5(1), 12-14.

Paulsen, M. B. (1990). College Choice: Understanding Student Enrollment Behavior. AAHEERIC Higher Education Report No. 6 Washington, D.C.: The George Washington University, School of Education and Human Development.

Riley, R.Q. (1995). Specialty cars for the 21st century: Downsized cars with upscale appeal. The Futurist, 29(6), 8-12.

Sanders, M. (1986). Recruitment strategies for industrial arts teachers education. The Journal of Epsilon Pi Tau, 12(1), 59-65.

Shaw, R. (1994). The place of industrial Technology in the $2+2+2$ tech prep concept. Journal of Industrial Technology, 10(2), 16-18.

Speelman, P. K., \& Stein, J. J. (1993). Factors that influence career choices made by EMU female industrial technology students. Journal of Industrial Technology, 9(4), 29-32.

Wanat, C. L., \& Bowles, B. D. (1992). College choice and recruitment of academically talented high school students. The Journal of College Admission, 136, 23-29.

Williams, J. K. (1993). A study of promotional strategies and the perceived contributions to traditional recruitment in higher education. Unpublished doctoral dissertation, Oklahoma State University.

Williams, W.G. (1980). Enrollment strategy. Charlottesville, VA: Share Publishing Co. 